\title{
NOTES ON THE OCCURRENCE OF JACAMARALCYON TRIDACTYLA (VIEILLOT) (AVES, PICIFORMES, GALBULIDAE) IN AN ATLANTIC FOREST FRAGMENT, MUNICIPALITY OF ANTÔNIO DIAS (MINAS GERAIS)
}

\author{
Ricardo Bomfim Machado 1,3 \\ Ludmilla M. de Souza Aguiar ${ }^{2,3}$ \\ Ivana Reis Lamas ${ }^{3}$ \\ Honorly K. Mestre Corrêa ${ }^{3}$
}

\begin{abstract}
A new occurrence for Jacamaralcyon tridactyla (Vieillot, 1817) for the state of Minas Gerais is registered here. Sone remarks about the species behavior are also included and compared with the sympatric species Galbula ruficauda Curvier. 1816

KEY WORDS. Aves. Jacamaralcyon tridactyla. Galbula ruficauda, behavior. distribution. Atlantic rain forest. Brazil
\end{abstract}

Jacamaralcyon tridactyla (Vieillot, 1817) is one of the Brazilian bird species considered to be threatened with extinction (BERNARDES et al. 1990), and there is an urgent need for studies on its current status (COLLAR et al. 1992). It is endemic to the Atlantic forest, occurring in the states of Bahia (the existing records are not precise), Minas Gerais and Espírito Santo, south to the state of Paraná (Meyer de Schauensee 1970; Sick 1985; Collar et al. 1992). The species was located in the state of Minas Gerais during ornithological inventories in the municipality of Antonio Dias, in the region of the Rio Doce, $19^{\circ} 40^{\prime} \mathrm{S}$ and $42^{\circ} 55^{\prime} \mathrm{W}$. The area where it was recorded (Fig. 1) belongs to the Companhia Siderúrgica Belgo-Mineira (CSBM) and is eucalyptus monoculture along with small patches of secondary Atlantic forest remnants.

\section{RESULTS}

The first record of Jacamaralcyon tridactyla was in August 1991, when just one individual was seen. During a second trip in November, however, eight individuals were recorded in two groups (four per group), about four kilometers

1) Fundação Biodiversitas. Avenida do Contorno 9155. 30110-130 Belo Horizonte. Minas Gerais. Brasil.

2) Conservation International. Avenida Antonio Abrahão Caram 82()/302, 31275-()(0) Belo Horizonte. Minas Gerais. Brasil.

3) Departamento de Zoologia. Instituto de Ciêneias Biológicas. Universidade Federal de Minas Gerais. Avenida Antônio Carlos 6627, 30161-970 Belo Horizonte. Minas Geraıs. Brasil. 
apart. These two groups were found in the natural vegetation between eucalyptus plantations. In both locations, the individuals were observed hunting in pairs, and there was a clear alternation of these possible couples during the hunting period. When the individuals succeeded in capturing an insect, they would then fly to the hollows located in a slope, and perch on a nearby branch. This short stop, which enabled the identification of the prey, was apparently made so that they could break the insect's chitinous body.

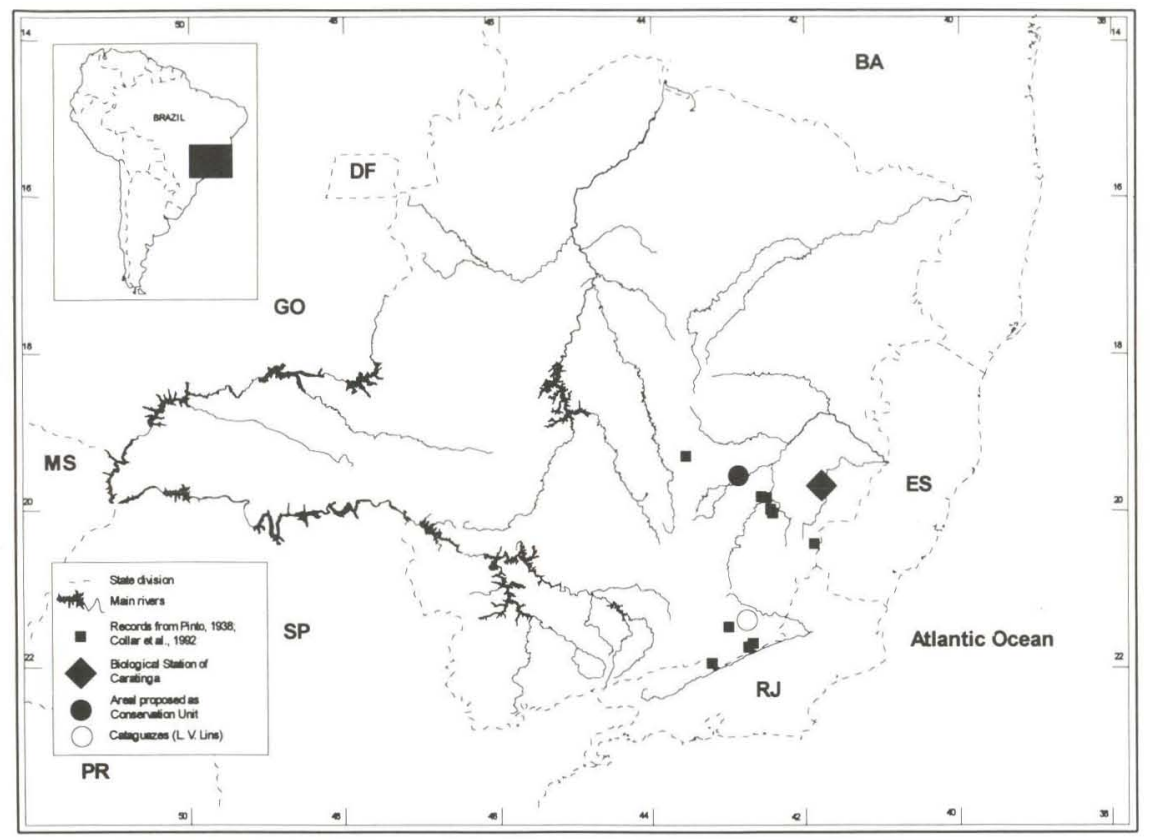

Fig. 1. Distribution of Jacamaralcyon tridactyla (Vieillot, 1817) in Minas Gerais. Squares are following PINTO (1938) and Collar et al. (1992). Circles are new occurences. The lozenge is the Biological Station of Caratinga.

While one individual was hunting, a second would remain near the perch, or inside the hollow or otherwise nearby. The other two individuals were always separated from the first pair, but hunting in a similar fashion. Despite the existence of groups of four individuals, the pairs were always separate. The prey items which could be identified included two species of Lepidoptera, one species of Hymenoptera, one species of Odonata, and two species of Orthoptera. As the prey were frequently carried to the hollows, it was suspected the presence of nestlings. Their behavior change when there was any movement near the slope. In this situation, the individuals stayed near the hollows, in an alert position, until there were nobody nearby. It was decided not to disturb the nests, limiting the activities only to the observation of the adults. According to SiCK (1985), the presence of numerous hollows in the slope, may be a way of misguiding the predators. 
Galbula ruficauda Cuvier, 1816, was also registered in the area. This second member of the Galbulidae was found hunting nearby, in the same manner as Jacamaralcyon tridactyla; that is from a perch. This species, however, hunted below Jacamaralcyon tridactyla up to near four meters.

\section{DISCUSSION}

As it has been recorded Jacamaralcyon tridactyla at only two sites, it is possible that the existing eucalyptus plantation represents a barrier for the local dispersion of this species. Galbula ruficauda, on the other hand, was recorded in many patches of eucalyptus, always alongside access roads. There is a recent record for the municipality of Cataguazes (Fig. 1) (L.V. Lins, personal communication) and for the Caratinga Biological Station (EBC), municipality of Caratinga. In this latter, Jacamaralcyon tridactyla was also recorded, in a site similar to the one found in Antonio Dias, in 1983 by N.E. Carnevalli, (personal communication). However, despite successive visits by R.B. Machado and L.M.S. Aguiar since 1986, it has not been recorded. Galbula ruficauda is easily observable in this area. As the EBC is the only place where the species could be found under some kind of protection (COLLAR et al. 1992), it has been proposed that the CSBM create a Private Natural Heritage Reserve (Reserva Particular do Patrimônio Natural - RPPN) a protected area category of the Brazilian Institute for the Environment (Ibama) in an area of about 400 ha on the banks of the Rio Piracicaba. Besides this, measures for the recuperation of the vegetation patches existing between the two points where Jacamaralcyon tridactyla was observed are recommended. By registering this new occurrence, it is hoped for calling attention to the lack of basic research on the geographical distributions, not only of bird species, but other animals, which is so important in the face of the constant and drastic environmental changes suffered by the entire Atlantic forest ecosystem.

ACKNOWLEDGMENTS. The study was carried for the environmental impact evaluation (EIA-RIMA) of the UHE Amorim II (CSBM) with the support of Ricardo Boaventura and Sonia Baumgratz, Ecodinâmica Ltda., Belo Horizonte, Minas Gerais. Thanks also to L.V. Lins and A.B. Rylands for their collaboration and suggestions.

\section{REFERENCES}

Bernardes, A.T.; A.B. MAChADO \& A.B. RYLAndS. 1990. Fauna brasileira ameaçada de extinção. Belo Horizonte, Fundação Biodiversitas, 62p.

Collar, N.J.; L.P. Gonzaga; N. Krabbe; A. Madroño Nieto; L.G. NaranJO; T.A. PARKER III \& D.C. WEGE. 1992. Threatened birds of the Americas. The ICBP/IUCN Red Data Book. Cambridge, Smithsonian Institution Press, 3rd ed., part 2, p.556-559.

Meyer De Schauensee, R. 1970. A guide to the birds of South America. The Academy of Natural Sciences of Philadelphia, 470p.

Pinto, O.M.O. 1938. Catálogo das aves do Brasil e lista dos exemplares que 
figuram no Museu Paulista. Revista do Museu Paulista 22: 305-306.

SıCK, H. 1985. Ornitologia brasileira: uma introdução. Brasilia, Universidade de Brasília, Vol. 1, 827P. 